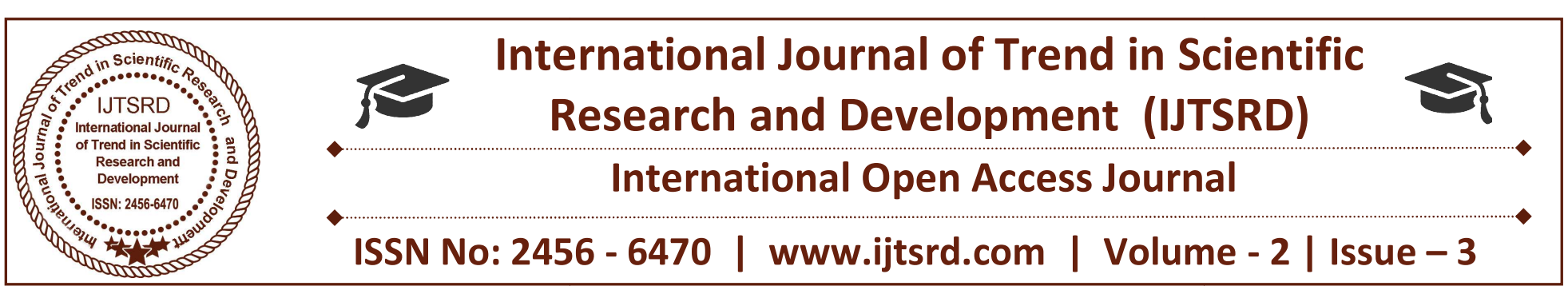

\title{
Estimate the Compressive and Flexural Strength Test of Natural and Recycle Concrete Aggregate
}

\author{
Ahad Ullah, Atiqur Rahman Alvi \\ Faculty, Department of Civil Engineering, \\ Port City International University (PCIU), Chittagong, Bangladesh
}

\begin{abstract}
Rapid industrial development causes depletion of natural aggregates, creates a huge amount of waste materials from constructional activities. To utilize recycle concrete aggregates in the production of concrete to reduce such problems. Use of recycle concrete aggregate in concrete is economical and environmentally viable. The main concern of this research is to reuse the demolished concrete as coarse aggregate for building a new structure. For this reason, the compressive strength as well as the flexural strength of natural concrete aggregate was compared with recycled concrete aggregate at different curing period. Also, the strength of mixed concrete (NRC) which contains half natural concrete aggregate and half recycles concrete aggregate was determined. Concrete made for recycle aggregate has both enough flexural strength and compressive strength. The 28 days compressive strength and flexural strength of recycle concrete were found 1975 psi and 676 psi respectively.
\end{abstract}

Keywords: natural concrete aggregate, recycle concrete aggregate, compressive strength, flexural strength

\section{INTRODUCTION}

Recycled concrete aggregate (RCA) is one of the main components of old concrete. Reusing of RCA has the benefit of reducing landfill disposal while conserving primary resources and reducing transport costs [1]. The conception of incorporating RCA in new concrete is not new; it has been around for a number of years. Various significant researches have been undertaken regarding the general performance of

RCA in concrete. After demolished of old roads and buildings, the demolished concrete is generally considered worthless and demolished waste [2]. Demolished concrete has been crushed sieved and decontaminated and it can be used as aggregate for the manufacturing of concrete [3].

The reasons for the increase of the volume of demolished concrete are many. Such as, demolished concrete from the old building, concrete pavement, bridges and other old structures have overcome their age and need to be demolished or they are not serving the needs in present scenario or incipient construction for better economic growth or debris resulting from various natural disasters like as earthquake, cyclone etc.

The properties of original concrete have a consequential influence on RCA concrete. Basically concrete containing RCA performed in a comparable manner to virgin concrete in terms of strength and durability $[4,5]$. However, the properties of durability can be improved with longer curing periods [5]. Working with RCA can be challenging since often the specifications about the pristine concrete are unknown [6]. RCA is highly heterogeneous and porous, with a substantial amount of impurities. So it is difficult to predict the resulting concrete properties and its durability. Recycled aggregate has higher water absorption and lowers specific gravity [7]. The cement mortar that is a component of the RCA significantly impacts the characteristics and performance of the RCA containing concrete [8]. Excessive adhered mortar on aggregate is the main 
factor affecting the properties of density, porosity as well as water absorption of RCA [2].

\section{MATERIALS}

In this research work, more than 50 years old recycled coarse aggregate were used. The demolished concrete were collected and then broken them into small size of $3 / 16$ to 1 inch to make recycle concrete aggregate which is commonly used as a coarse aggregate in Bangladesh. The natural concrete aggregate (NCA) of 16 to 1 inch size was used as coarse aggregate. 2.87 FM sand was used as fine aggregate and Portland lime stone cement as binder material.

\section{METHODS}

The mix design was done by British standard method for attaining $3000 \mathrm{psi}$ strength. The mix design ratio of concrete was 1:1.25:2.4 and water cement ratio was 0.485 . To determine the workability of concrete, slump test was conducted according to ASTM C143 [9]. The compressive and flexural strength test were carried out according to ASTM C39 [10] and ASTM C78 [11] method respectively. The compressive strength was done by using a hydraulic compression machine and the flexural strength test by using third point loading.

\section{RESULT AND DISCUSSION}

Specific gravity test was done by ASTM C33 [12] and found 2.64 and 2.60 for normal coarse aggregate and recycled coarse aggregate respectively. Whereas apparent specific gravity was found 2.70 and 2.65 and water absorption $0.8 \%$ and $0.84 \%$ respectively.

\section{Table 1: Value of slump test}

\begin{tabular}{|l|l|}
\hline Type & Slump $(\mathrm{mm})$ \\
\hline NCA & 144 \\
\hline RCA & 149 \\
\hline NRC & 145 \\
\hline
\end{tabular}

The workability of recycle concrete is higher than natural concrete aggregate though the water was kept constant. To determine the 7,14 and 28 days compressive and flexural strength of both NCA and RCA concrete, the specimens were immersed in water at room temperature until the age of testing. The specimens were tested after achieving the saturated surface dry conditions. Total 27 cylindrical columns were made within 7,14 and 28 days for compressive strength test which diameter was 4 inch and height 8 inch. The average compressive strength test result for NCA, RCA and NRC are shown in table 2.

Table 2: Compressive strength test result

\begin{tabular}{|l|l|l|l|}
\hline Type & \multicolumn{3}{|l|}{ Compressive strength average (psi) } \\
\hline & 7 Days & 14 Days & 28 Days \\
\hline NCA & 2109 & 2434 & 2790 \\
\hline RCA & 1521 & 1723 & 1975 \\
\hline NRC & 1789 & 1938 & 2168 \\
\hline
\end{tabular}

By comparing those values it is found that the compressive strength of NCA is much higher than recycle concrete and mixed concrete. The compressive strength of mixed concrete also found higher than the recycled concrete. As the watercement ratio was 0.485 , the percentage of the reduction rate of compressive strength was high. The RCA customarily reduce concrete compressive strength because of high water absorption of the aggregate and the impotent residual mortar layer. If the source concrete is more vigorous than that at which the RCA concrete is intended to perform, it is possible to produce concrete that is more vigorous than a conventional concrete.

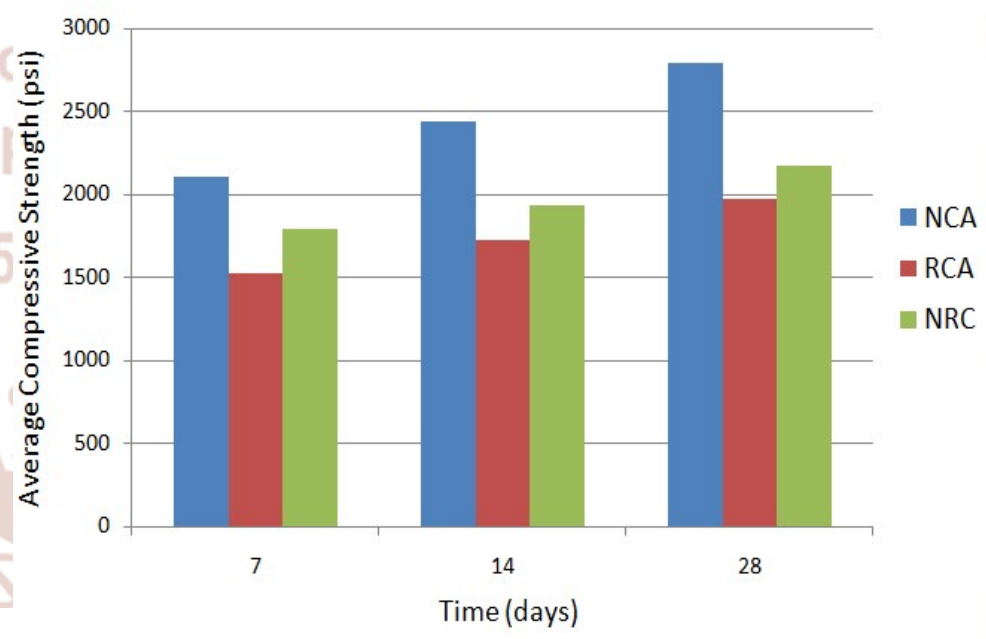

Fig.1. Compressive strength for NCA, RCA and NRC

From the figure 1, it is found that 28 days strength of normal concrete is $29.21 \%$ higher than recycled concrete and $22.30 \%$ higher than mixed concrete. According to Bangladesh National Building Code, minimum concrete strength for structural use of reinforced concrete shall be 2900 psi and building up to four storied minimum concrete strength may be relaxed to 2465 psi [13]. So RCA can be used for 2-3 storied building. 
International Journal of Trend in Scientific Research and Development (IJTSRD) ISSN: 2456-6470

Total 27 beams were made within 7, 14 and 28 days for the flexural strength test. The average flexural strength test result for NCA, RCA and NRC are shown in table 3.

Table 3: Flexural strength test result

\begin{tabular}{|l|l|l|l|}
\hline Type & \multicolumn{3}{|l|}{ Flexural strength average (psi) } \\
\hline & 7 Days & 14 Days & 28 Days \\
\hline NCA & 647 & 704 & 722 \\
\hline RCA & 535 & 602 & 676 \\
\hline NRC & 569 & 642 & 693 \\
\hline
\end{tabular}

RCA content was found to have less significant effects on flexural strength compared to concrete made with virgin aggregate [14]. For 28 days, flexure test result of NCA and RCA are almost similar. The RCA contains $6.37 \%$ less flexural strength than NCA.

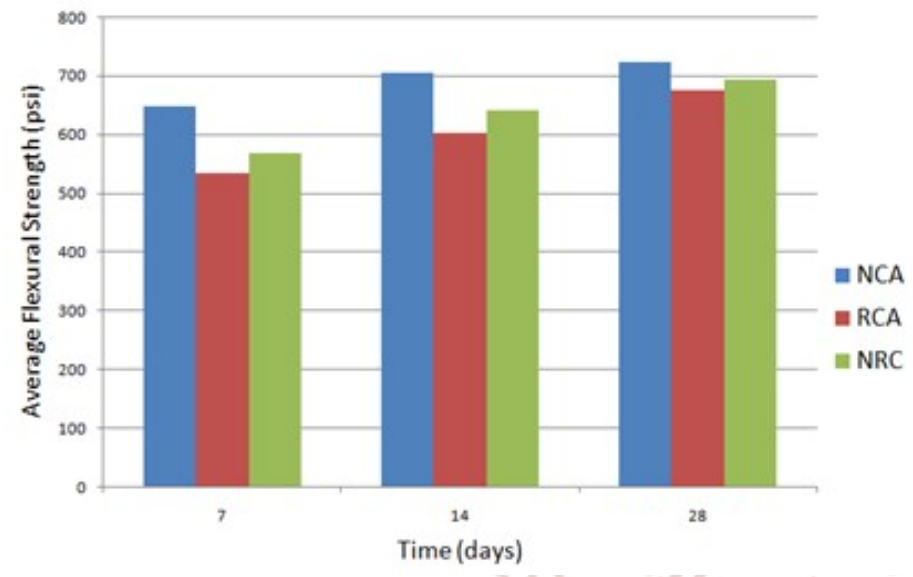

Fig.2. Flexural strength for NCA, RCA and NRC

According to the ACI 555 committee report, RCA concrete has around the same or $10 \%$ less flexural strength than concrete containing NCA. Flexural strength decreases $4.19 \%$ in case of mix concrete which contains half RCA and half NCA. Mixed concrete gives much better result than RCA concrete which is approximately same with NCA.

\section{CONCLUSION}

Recycle concrete aggregate has both enough flexural strength and compressive strength but less strength than the natural concrete aggregate. It can be summarized that standard concrete or natural concrete aggregate is suitable for high rise structure where recycled concrete and mixed concrete is not. Recycled concrete and mixed concrete can be used up to four storied building.

\section{REFERENCES}

1. Oikonomou, N.D. 2004. "Recycle concrete aggregate" Journal of Cement and Concrete Composites 27 (2005) "315-318”

2. Katrina McNeil \& Thomas H.-K. Kang. 2013. Recycled Concrete Aggregates: A Review of International journal of concrete structures \& materials, Vol. 7, pp. 61-69, March 2013.

3. Mukesh C., Limbachiya, J. J., \& Roberts, 2004. Construction Demolition Waste, pp. 64.

4. Shayan A., and Xu, A. 2003. "Performance and Properties of Structural Concrete Made with Recycled Concrete Aggregate," ACI Materials Journal, V. 100, No. 5, September October 2003, pp. 371-380.

5. Olorunsogo, F.T., and Padayachee, N. 2002. "Performance of Recycled Aggregate Concrete Monitored by Durability Indexes," Cement and Concrete Research, V. 32, No. 2, 2002, pp. 179185.

6. Oikonomou, N.D. 2005. "Recycled Concrete Aggregates," Cement and Concrete Composites, V. 25, No. 2, pp. 315-318.

7. Dr. M.A. Aziz, 1995. A Text Book of Engineering Materials by Dr. M.A. Aziz, Z\&Z Computer \& Printers, Dhaka, Bangladesh.

8. Sagoe-Crentsil, K.K., Brown, T., and Taylor, A.H. 2001. "Performance of Concrete Made with Commercially Produced Coarse Recycle Concrete Aggregate," Cement and Concrete Research, V. 31, No. 5, pp. 707-712.

9. ASTM C143, 2003. American Society for Testing and Materials C143,( Standard test method for slump of Hydraulic-Cement Concrete) Annual Book of ASTM Standard, 2003.

10. ASTM C39, 2003. American Society for Testing and Materials C 39 (Standard test for compressive strength of Concrete), Annual Book of ASTM Standard, 2003.

11. ASTM C78, 2003. American Society for Testing and Materials C 78 Standard Test Method for Flexural Strength of Concrete (Using Simple Beam with Third-Point Loading) Annual Book of ASTM Standard, 2003. 
12. ASTM C33, 2003. American Society for Testing and Materials C33, Standard Specification for Concrete Aggregates Annual Book of ASTM Standard, 2003.

13. BNBC 2012 Bangladesh National Building Code, volume 2 to 3 , part 6 , Structural design.

14. Xiao, J. Z. and Li, J. B. 2005. "Study on relationships between strength indexes of recycled concrete (in Chinese)", Chinese Journal of Building Material 9: 197-201. 